\title{
STRUKTUR KOMUNITAS UDANG (CRUSTACEA) DI SUNGAI TELUK SEPAKU, KELURAHAN PULAU BULUH KECAMATAN BULANG KOTA BATAM.
}

\section{THE STRUCTURE COMMUNITY OF THE SHRIMP (CRUSTACEA) AT TELUK SEPAKU RIVER, BULUH, BULANG DISTRICT, BATAM ISLAND}

\author{
Jumariah Jumariah ${ }^{1}$, Fenny Agustina $*^{2}$, Notowinarto Notowinarto ${ }^{3}$ \\ ${ }^{1,2,3}$ Program Studi Pendidikan Biologi, FKIP, Universitas Riau Kepulauan, Batam \\ *Koresponden: fennyagustina@gmail.com
}

\begin{abstract}
Abstrak
Sebagai wilayah kepulauan, Kota Batam dikelilingi lautan yang terdapat pulau-pulau kecil atau disebut sebagai kawasan hinterlands. Sejauh ini belum diketahui ragam jenis udang yang ada karena itu dilakukan penelitian tentang struktur komunitas udang (Crustacea) di Sungai Teluk Sepaku, tujuan mengkaji ragam dan jenis udang pada kawasan sungai Teluk Sepaku. Penelitian ini menggunakan metode deskriptif kuantitatif, dilaksanakan pada bulan April - Juni 2013. Sampel udang diambil dari 5 stasiun pengamatan menggunakan sudu (jala penyorong) dan tekop. Hasil identifikasi dan analisis didapatkan 7 spesies udang kelas Crustacea, ordo Decapoda dan 2 famili Penaeidae dan Palaemonidae, yakni; Penaeus latisulcatus, Metapenaeus affinis, Penaeus sp (1), Penaeus sp (2), Penaeus indicus, Penaeus monodon dan Macrobrachium sp. Hasil analisis korelasi menunjukkan bahwa terdapat hubungan antara kemelimpahan beberapa udang, yaitu antara Penaeus monodon dengan Penaeus sp (2). Sedangkan tingkat similaritas udang antar tiap stasiun pengamatan adalah tinggi dan terdiri dari 2 (dua) kelompok, yaitu kelompok 1 : hanya mencakup Stasiun 1. Lokasi stasiun 1 dan keempat lokasi stasiun penelitian udang lainnya hanya memiliki tingkat similaritas 22,83\%. Kelompok 2: Stasiun 2, Stasiun 3, Stasiun 4 dan Stasiun 5. Lokasi stasiun 2, stasiun 4 dan stasiun 5 memiliki tingkat similaritas 46,26\%. Lokasi stasiun 2 dan stasiun 4 memiliki tingkat similaritas $79,86 \%$.
\end{abstract}

Kata Kunci: Udang, Struktur Komunitas, Udang, Perairan Selat.

\begin{abstract}
Abstrac
As an archipelago area, Batam city is surrounded by seas with many isles or called as Hinterlands. So far, it is unknown the number of shrimp variety, that is why this research is conducted to ivstigate shrimp structure community (Crustacea) at Teluk Sepaku river. The aims of this study is to investigate varieties and kinds of shrim at around Teluk Sepaku river. This research used descriptive qualitative reseaerch, conducted on April to june 2013. Shrimp sample were taken from 5 stations and observations using the blade or net Skidders (sudu) and tekop. Identification and analysis result showed 7 species of shrimp crustaceans, order Decapoda and 2 Penaeidae family species and Palaemonidae, namely; latisulcatus penaeus, Metapenaeus affinis, Penaeus sp (1), Penaeus sp (2), Penaeus indicus, Penaeus monodon and Macrobrachium sp. The results of correlation analysis showed that there is an abundance shrimp, between the Penaeus monodon and Penaeus sp (2). meanwhile the level of shrimp's similarity among observation stations was high and consists of 2 (two) groups, namely Group 1: includes only 1 station.; station 1 and other stations get 22.83\% similarity level. Group 2: Station 2, Station 3, Station 4 and Station 5. Station 2, station 4 and station 5 had 46.26\% similarity level. Station 2 and station 4 had $79.86 \%$ similarity level.
\end{abstract}

Keywords: Shrimp, Structure Community, Hinterlands, Strait, 


\section{PENDAHULUAN}

Sebagai bagian dari ekosistem perairan laut, udang berperan dalam menjaga keseimbangan ekosistem dan berfungsi sebagai salah satu rantai makanan yang sangat penting, yakni udang merupakan mangsa dari hewan akuatik yang lebih besar seperti ikan. Apabila udang tidak terdapat di perairan, maka perairan tersebut akan mengalami pembusukan yang dapat meningkatkan zat amoniak dan bersifat racun yang secara langsung dapat mempengaruhi populasi dan keanekaragaman kehidupan hewan perairan lainnya. Udang hidup disemua jenis habitat perairan dengan $89 \%$ diantaranya hidup di perairan laut, $10 \%$ diperairan air tawar dan 1\% di perairan terrestrial (Abele, 1982 dalam Sembiring, 2008).

Udang laut merupakan tipe yang tidak mampu atau mempunyai kemampuan terbatas dalam mentolerir perubahan salinitas. Kelompok ini biasanya hidup terbatas pada daerah terjauh dari estuaria yang umumnya mempunyai salinitas $30 \mathrm{ppt}$ atau lebih. Kelompok yang mempunyai kemampuan untuk mentolerir variasi penurunan salinitas sampai di bawah 30 ppt hidup di daerah terrestrial dan menembus hulu estuaria dengan tingkat kejauhan bervariasi sesuai dengan kemampuan spesies untuk mentolerir penurunan tingkat salinitas. Kelompok terakhir adalah udang air tawar.Udang dari kelompok ini biasanya tidak dapat mentolerir salinitas di atas 5 ppt. Udang menempati perairan dengan berbagai tipe pantai seperti pantai berpasir, berbatu ataupun berlumpur. Spesies yang dijumpai pada ketiga tipe pantai ini berbeda-beda sesuai dengan kemampuan masing-masing spesies menyesuaikan diri dengan kondisi fisik-kimia perairan (Nybakken, 1992). Menurut Martosubroto dan Naamin (1989), daerah penyebaran udang sangat dipengaruhi oleh keadaan dasar perairan, yaitu menyenangi daerah lumpur dan bercampur pasir serta didukung oleh keberadaan hutan mangrove dan masukan massa air.

Sebagai wilayah kepulauan, Kota Batam dikelilingi lautan yang terdapat pulaupulau kecil atau disebut sebagai kawasan hinterland, berpenghuni masyarakat bermata pencaharian sebagai nelayan. Masyarakat nelayan cenderung banyak menangkap udang, kemudian hasil tangkapan dijual ke masyarakat pesisir setempat, ke pasar-pasar lokal Batam atau dikirim keluar daerah bahkan keluar negeri (pasar Singapura dan Malaysia) setelah dikumpulkan oleh pedagang pengumpul udang. Kegiatan menangkap udang masih menggunakan cara tradisional yaitu "sudu" atau dengan alat khusus disebut "tekop". 
Adanya kegiatan penangkapan udang di perairan Kecamatan Bulang memungkinkan banyaknya jenis udang dan potensi produksi yang terdapat di perairan kawasan khususnya di lokasi perairan selat yang terletak diantara pulau Teluk Sepaku dan pulau Tanjung Kubu yang disebut dengan selat Teluk Sepaku yang termasuk di kelurahan Pulau Buluh. Banyak nelayan yang menangkap udang di daerah tersebut dikarenakan selat Teluk Sepaku memiliki dua muara yang memungkinkan udang masuk dari kedua arah dan berkumpul di selat tersebut. Namun, sejauh ini belum diketahui ragam jenis udang yang ada di selat Teluk Sepaku. Hal tersebut dikarenakan belum adanya data tertulis mengenai jenis udang di perairan ini. Oleh karena itu perlu dilakukan penelitian tentang "Struktur Komunitas Udang (Crustacea) Di Selat Teluk Sepaku, Kelurahan Pulau Buluh Kecamatan Bulang Kota Batam”.

\section{METODOLOGI}

Pengamatan dan pengambilan data penelitian mencangkup seluruh individu yang terdapat dalam suatu wilayah perairan yakni sebagai bagian dari studi sensus. Jadi populasi pada penelitian ini adalah semua jenis udang yang ditangkap di Selat Teluk Sepaku selama bulan April sampai Juni 2013. Sedangkan pengambilan sampel dilakukan secara acak (random) yakni jenis-jenis udang berdasarkan volume hasil tangkapan dari Stasiun pengambilan sampel yang telah ditentukan.

Dalam penelitian ini digunakan teknik deskriptif yakni melakukan identifikasi jenis udang menggunakan buku rujukan "A Guide to The Shrimps, and Crabs of Malaysia and Singapore", "A Colour Guide To The Fishes Of The South China Sea And Andaman Sea” dan "Klasifikasi Ikan Laut Untuk Statistika Perikanan Tangkap”. Data yang dikumpulkan adalah: a) data primer adalah jenis komposisi jenis, jumlah populasi dan jenis, tahapan pertumbuhan, keanekaragaman, keseragaman dan dominansi; b) data sekunder adalah keadaan kualitas perairan dengan menggunakan parameter fisik kimia, meliputi suhu, salinitas, Oksigen terlarut (DO), pH, DHL, Fosfat, Nitrat dan Amonia. Lebih lanjut dilakukan analisis data; Struktur Komunitas akan dengan Indeks Shannon untuk diversitas umum (H'), Indeks Evenness (E), dan Indeks Dominans (C). Analisis lanjutan adalah melakukan uji statistik untuk Analysis Cluster dan Analysis Correlation untuk mengetahui adanya korelasi dan tingkat hubungan hasil tangkapan udang perstasiun pengamatan. 


\section{PEMBAHASAN}

Kondisi fisik kimia kualitas perairan Stasiun pengamatan dipengaruhi oleh beberapa unsur yaitu salinitas (ppt), suhu air yang terdiri dari suhu air permukaan dan suhu air dalam $\left({ }^{0} \mathrm{C}\right)$, DO (ppm), pH, Amonium $\left(\mathrm{NH}_{4}-\mathrm{OH} / \mathrm{Mg} \cdot \mathrm{L}^{-1}\right)$, Nitrat $\left(\mathrm{NO}_{3}{ }^{-}\right.$ $\left.\mathrm{N} / \mathrm{Mg} . \mathrm{L}^{-1}\right)$, dan Fosfat $\left(\mathrm{PO}_{4}-\mathrm{P} / \mathrm{Mg} . \mathrm{L}^{-1}\right)$ dan DHL (m.V).Unsur-unsur tersebut mempengaruhi jenis serta jumlah udang pada setiap stasiun pengamatan (Tabel 1).

Tabel 1. Data Parameter Lingkungan Perairan Setiap Stasiun Pengamatan

\begin{tabular}{lccccc}
\hline \multirow{2}{*}{\multicolumn{1}{c}{ PARAMETER }} & \multicolumn{5}{c}{ STASIUN } \\
\cline { 2 - 6 } & $\mathbf{1}$ & $\mathbf{2}$ & $\mathbf{3}$ & $\mathbf{4}$ & $\mathbf{5}$ \\
\hline Salinitas (ppt) & 24,25 & 25,00 & 27,00 & 27,00 & 27,67 \\
Suhu Air Permukaan $\left({ }^{\circ} \mathrm{C}\right)$ & 29,43 & 29,37 & 29,65 & 29,90 & 29,80 \\
Suhu Air Dalam $\left({ }^{\circ} \mathrm{C}\right)$ & 31,60 & 32,00 & 31,63 & 32,15 & 31,97 \\
DO (ppm) & 5,11 & 4,98 & 6,30 & 6,45 & 5,69 \\
DHL (m.V) & 26,88 & 35,05 & 38,3 & 45,38 & 41,58 \\
pH & 7,76 & 8,07 & 8,14 & 8,03 & 8,14 \\
Amonia $\left(\mathrm{NH}_{4}-\mathrm{OH} / \mathrm{Mg} . \mathrm{L}^{-1}\right)$ & 1,00 & 1,00 & 0,5 & 1,00 & 1,25 \\
Nitrat $\left(\mathrm{NO}_{3}-\mathrm{N} / \mathrm{Mg} \cdot \mathrm{L}^{-1}\right)$ & 36,67 & 40,00 & 30,00 & 40,00 & 30,00 \\
Fosfat $\left(\mathrm{PO}_{4}\right.$-P/Mg.L $\left.\mathrm{L}^{-1}\right)$ & 0,50 & 0,60 & 0,20 & 0,50 & 0,30 \\
\hline
\end{tabular}

Dari hasil penelitian ini ditemukan 7 (tujuh) jenis udang yaitu Metapenaeus affinis (udang merah muda), Penaeus indicus, Penaeus monodon (udang windu), Penaeus latisulcatus (udang raja), Penaeus sp (1), Penaeus sp (2) dan Macrobrachium $s p$ (udang galah).

Tabel 2. Keberadaan Jenis Udang di Setiap Stasiun

\begin{tabular}{clccccc}
\hline No & \multicolumn{1}{c}{ Jenis Udang } & Stasiun 1 & Stasiun 2 & Stasiun 3 & Stasiun 4 & Stasiun 5 \\
\hline 1 & Metapenaeus affinis & + & + & + & + & + \\
2 & Penaeus indicus & + & + & + & + & + \\
3 & Penaeus monodon & - & - & + & + & - \\
4 & Penaeus latisulcatus & + & + & + & - & - \\
5 & Penaeus sp $(1)$ & + & - & + & - & - \\
6 & Penaeus $s p(2)$ & + & - & + & - & - \\
7 & Macrobrachium sp & - & - & + & - & - \\
\hline
\end{tabular}

Keterangan : +/Ada dan - /Tidak Ada

Pada Tabel 2 dapat dilihat bahwa jenis udang yang paling banyak ditemukan pada stasiun 3, yaitu terdapat 7 (tujuh) jenis udang yaitu Metapenaeus affinis (udang merah muda), Penaeus indicus, Penaeus monodon (udang windu), Penaeus latisulcatus 
(udang raja), Penaeus sp (1), Penaeus sp (2), dan Macrobrachium sp (udang galah). Seluruh jenis udang dapat hidup di stasiun 3, dikarenakan kondisi lingkungan stasiun 3 yang merupakan sedimen berpasir yang dapat dijadikan sebagai habitat semua jenis udang. Selain itu, oksigen terlarut pada stasiun 3 berkadar 6,30 ppm yang mengakibatkan udang dapat hidup dengan baik. Menurut Erlangga (2012), udang dapat berkembang dengan baik apabila kadar oksigen habitatnya tinggi (lebih besar dari 4 ppm). Selain itu, Stasiun 3 merupakan pertemuan arus dari dua arah yang berbeda yaitu dari Stasiun 1 dan Stasiun 5 serta dari aliran air laut di sela-sela hutan bakau yang terdapat di Stasiun 3 sehingga memungkinkan menjadi tempat berkumpulnya seluruh udang.

Sedangkan jenis udang yang paling sedikit ditemukan adalah pada stasiun 5, yaitu 2 (dua) jenis udang yaitu Metapenaeus affinis (udang merah muda) dan Penaeus indicus. Hal ini dikarenakan oleh zat amonia yang terdapat pada stasiun 5 sangat tinggi yaitu $1,25 \mathrm{mg} . \mathrm{L}^{-1}$ yang menyebabkan udang tidak dapat hidup pada habitat ini. Menurut Erlangga (2012), kadar amonia pada air tambak sekitar 1,29 mg. $\mathrm{L}^{-1}$, akan menyebabkan udang keracunan dan pada akhirnya banyak udang yang mati.

Jenis udang yang ditemukan pada setiap stasiun pengamatan diambil sampel acak sebanyak $10 \%$ dari jumlah hasil tangkapan. Hasil pengamatan atas morfometrik dari jumlah individu udang, rerata berat udang, panjang total udang dan diameter udang yang ditemukan dapat dilihat pada Tabel 3 sampai Tabel 6.

Tabel 3. Jumlah Individu Udang yang Ditemukan pada Setiap Stasiun Pengamatan

\begin{tabular}{clccccc}
\hline No & Jenis Udang & Stasiun 1 & Stasiun 2 & Stasiun 3 & Stasiun 4 & Stasiun 5 \\
\hline 1 & Metapenaeus affinis & 3 & 5 & 14 & 5 & 18 \\
2 & Penaeus indicus & 29 & 11 & 15 & 5 & 3 \\
3 & Penaeus monodon & 0 & 0 & 10 & 3 & 0 \\
4 & Penaeus latisulcatus & 3 & 2 & 2 & 0 & 0 \\
5 & Penaeus sp (1) & 1 & 0 & 2 & 0 & 0 \\
6 & Penaeus sp (2) & 1 & 0 & 4 & 0 & 0 \\
7 & Macrobrachium sp & 0 & 0 & 1 & 0 & 0 \\
\hline & Jumlah & 37 & 18 & 47 & 13 & 21 \\
\hline
\end{tabular}


Tabel 4. Rata-Rata Berat Udang (gram) yang Ditemukan pada Setiap Stasiun Pengamatan

\begin{tabular}{clccccc}
\hline No & Jenis Udang & Stasiun 1 & Stasiun 2 & Stasiun 3 & Stasiun 4 & Stasiun 5 \\
\hline 1 & Metapenaeus affinis & 4,10 & 14,00 & 6,07 & 6,80 & 8,17 \\
2 & Penaeus indicus & 6,14 & 3,18 & 5,67 & 7,20 & 8,33 \\
3 & Penaeus monodon & - & - & 7,10 & 6,67 & - \\
4 & Penaeus latisulcatus & 8,20 & 8,20 & 5,50 & - & - \\
5 & Penaeus sp (1) & 10,00 & - & 2,00 & - & - \\
6 & Penaeus sp (2) & 13,00 & - & 16,25 & - & - \\
7 & Macrobrachium sp & - & - & 4,00 & - & - \\
\hline
\end{tabular}

Tabel 5. Rata-Rata Panjang Total $(\mathrm{cm})$ Udang yang Ditemukan pada Setiap Stasiun Pengamatan

\begin{tabular}{clccccc}
\hline No & Jenis Udang & Stasiun 1 & Stasiun 2 & Stasiun 3 & Stasiun 4 & Stasiun 5 \\
\hline 1 & Metapenaeus affinis & 8,91 & 8,54 & 9,24 & 9,72 & 10,80 \\
2 & Penaeus indicus & 10,62 & 8,98 & 9,60 & 11,21 & 11,12 \\
3 & Penaeus monodon & - & - & 10,05 & 10,00 & - \\
4 & Penaeus latisulcatus & 11,75 & 8,62 & 9,29 & - & - \\
5 & Penaeus sp (1) & 11,63 & - & 2,63 & - & - \\
6 & Penaeus sp (2) & 13,14 & - & 12,86 & - & - \\
7 & Macrobrachium sp & - & - & 10,10 & - & - \\
\hline
\end{tabular}

Tabel 6. Rata-Rata Diameter Tubuh (cm) Udang yang Ditemukan pada Setiap Stasiun Pengamatan

\begin{tabular}{clccccc}
\hline No & Jenis Udang & Stasiun 1 & Stasiun 2 & Stasiun 3 & Stasiun 4 & Stasiun 5 \\
\hline 1 & Metapenaeus affinis & 3,27 & 3,32 & 3,76 & 3,94 & 4,26 \\
2 & Penaeus indicus & 4,09 & 3,41 & 3,62 & 4,39 & 4,36 \\
3 & Penaeus monodon & - & - & 4,10 & 4,07 & - \\
4 & Penaeus latisulcatus & 4,29 & 3,22 & 3,56 & - & - \\
5 & Penaeus sp (1) & 4,66 & - & 2,14 & - & - \\
6 & Penaeus sp (2) & 5,15 & - & 5,04 & - & - \\
7 & Macrobrachium sp & - & - & 4,00 & - & - \\
\hline
\end{tabular}

Pada Tabel 4. berat Metapenaeus affinis tertinggi terdapat pada stasiun 2 dan berat terendah terdapat pada stasiun 1. Berat Penaeus indicus tertinggi terdapat pada stasiun 5 dan berat terendah terdapat pada stasiun 2. Berat Penaeus monodon tertinggi terdapat pada stasiun 3 dan berat terendah terdapat pada stasiun 4. Berat Penaeus latisulcatus tertinggi terdapat pada stasiun 1 dan stasiun 2 dan berat terendah terdapat 
pada stasiun 3. Berat udang jenis Penaeus sp (1) tertinggi terdapat pada stasiun 1 dan berat terendah terdapat pada stasiun 3. Berat Penaeus sp (2) tertinggi terdapat pada stasiun 3 dan berat terendah terdapat pada stasiun 1. Berat rata-rata udang jenis Macrobrachium sp adalah 4,00 gram.ekor ${ }^{-1}$

Pada Tabel 5 rata-rata panjang total Metapenaeus affinis tertinggi terdapat pada stasiun 5 dan terendah terdapat pada stasiun 2. Rata-rata panjang total Penaeus indicus tertinggi terdapat pada stasiun 4 dan terendah terdapat pada stasiun 2. Rata-rata panjang total Penaeus monodon tertinggi terdapat pada stasiun 3 dan terendah terdapat pada stasiun 4. Rata-rata panjang total Penaeus latisulcatus tertinggi terdapat pada stasiun 1 dan terendah terdapat pada stasiun 2. Rata-rata panjang total Penaeus sp (1) tertinggi terdapat pada stasiun 1 dan terendah terdapat pada stasiun 3. Rata-rata panjang total Penaeus sp (2) tertinggi terdapat pada stasiun 1 dan terendah terdapat pada stasiun 3.

Pada Tabel 6 rata-rata diameter tubuh Metapenaeus affinis tertinggi terdapat pada stasiun 5 dan terendah terdapat pada stasiun 1. Rata-rata diameter tubuh Penaeus indicus tertinggi terdapat pada stasiun 4 dan terendah terdapat pada stasiun 2. Rata-rata diameter tubuh Penaeus monodon tertinggi terdapat pada stasiun 3 dan terendah terdapat pada stasiun 4. Rata-rata diameter tubuh Penaeus latisulcatus tertinggi terdapat pada stasiun 1 dan terendah terdapat pada stasiun 2. Rata-rata diameter tubuh Penaeus sp (1) tertinggi terdapat pada stasiun 1 dan berat terendah terdapat pada stasiun 3. Ratarata diameter tubuh Penaeus sp (2) tertinggi terdapat pada stasiun 1 dan terendah terdapat pada stasiun 3 .

Analisis data struktur komunitas udang meliputi; keanekaragaman, keseragaman, dan dominansi berdasarkan data jumlah keseluruhan sampling (ekor) jenis udang yang ditemukan atau tertangkap pada seluruh Stasiun (tabel 7).

Tabel 7. Nilai Indeks Keanekaragaman, Keseragaman dan Dominansi Pada Stasiun Pengamatan

\begin{tabular}{cccc}
\hline Stasiun & Nilai Indeks H' & Nilai Indeks E' & Nilai Indeks D' \\
\hline 1 & 0,34 & 0,49 & 0,63 \\
2 & 0,39 & 0,82 & 0,46 \\
3 & 0,68 & 0,80 & 0,25 \\
4 & 0,45 & 0,94 & 0,38 \\
5 & 0,18 & 0,59 & 0,76 \\
\hline
\end{tabular}

Dari kelima stasiun nilai Indeks keanekaragaman ( $\left.\mathrm{H}^{\prime}\right)$ adalah antara 0,18 sampai 
0,68 artinya bahwa pada semua stasiun pengamatan adalah nilai keanekaragaman dengan katagori rendah. Menurut Wedjatmiko dan Cholik (1989) dalam Sembiring (2008), akar-akar pohon mangrove selain baik bagi larva udang juga sebagai tempat berlindung dari serangan predator sampai tumbuh menjadi udang muda dan dewasa, bakau juga menyediakan bahan organik kaya nutrisi yang diperlukan untuk pertumbuhan udang. Bower et al (1990) dalam Sembiring (2008), menyatakan bahwa suatu komunitas dikatakan mempunyai keanekaragaman spesies yang tinggi apabila terdapat spesies dengan jumlah individu masing-masing spesies relatif merata.

Nilai Indeks Keanekaragaman (H') cukup baik pada semua stasiun terdapat pada Stasiun 3 adalah merupakan lokasi perairan merupakan kawasan bersedimen gumuh pasir dengan beranekaragam flora darat maupun flora air yang cukup baik, serta merupakan pertemuan masuknya air dari arah barat maupun arah timur. Perubahan secara hidrologis kondisi kualitas air saat pergantian pasang surut sangat baik dan menyebabkan perairan cenderung mengalami perubahan kadar garam maupun bahan organik lainnya menjadi cukup drastis sehingga hanya beberapa spesies udang yang mampu beradaptasi.

Nilai Indeks keseragaman (E') tertinggi terdapat pada stasiun 4 dengan nilai indeks 0,94 yang berarti pada stasiun 4 memiliki indeks keseragaman spesies udang yang tinggi karena jumlah individu tiap jenis udang. Pada stasiun 4 tidak jauh berbeda. Sedangkan nilai Indeks keseragaman (E') terendah terdapat pada stasiun 1 dengan nilai indeks 0,49 yang artinya stasiun 1 memiliki keseragaman spesies udang yang rendah. Hal ini disebabkan oleh jumlah individu tiap jenis udang pada stasiun 1 sangat jauh berbeda. Menurut Krebs (1985) dalam Sembiring (2008), nilai keseragaman berkisar antara 0 - 1, jika nilai keseragaman mendekati 0 berarti keseragaman suatu populasi rendah dan penyebaran jenis tidak merata serta ada kecenderungan dominansi suatu jenis pada populasi, dan bila mendekati 1 keseragaman tinggi yang menunjukkan tidak ada jenis yang mendominansi. Dengan demikian kondisi perairan pada Selat Teluk Sepaku dapat dikategorikan sebagai ekosistem yang ideal bagi kehidupan berbagai jenis udang. Keseragaman antar spesies di dalam komunitas mencerminkan keseragaman yang dimiliki masing-masing spesies tidak jauh berbeda dan lokasi ini bisa ideal dan bisa tidak bagi kehidupan udang tergantung dari kondisinya. 
Nilai Indeks dominansi (D') pada stasiun 1 dan stasiun 5 menunjukkan bahwa terdapat spesies udang yang mendominansi sangat tinggi dengan tingkat dominansi tertinggi terdapat pada stasiun 5 dengan nilai indeks sebesar 0,76. Spesies udang yang paling mendominasi pada stasiun 5 adalah udang Metapenaeus affinis. Stasiun 2 dan stasiun 4 termasuk ke dalam indeks dominansi sedang. Indeks dominansi pada stasiun 3 termasuk ke dalam indeks dominansi rendah dengan nilai indeks sebesar 0,25.

Nilai Indeks Dominansi berhubungan terbalik dengan keragamaan dan keseragaman sedangkan antara Indeks Keanekaragaman dan Keseragaman mempunyai hubungan yang positif. Menurut Odum (1998) dan Indrawan, $d k k$ (2007), nilai Indeks Dominansi berkisar antara 0 - 1 dan jika nilai indeks mendekati atau bernilai 1 , maka perairan didominansi oleh spesies tertentu dan sebaliknya. Indeks Dominansi tertinggi terdapat pada stasiun 1 dan stasiun 5yang berarti di dalam komunitas tidak ada spesies yang mendominansi secara nyata terhadap spesies lainnya. Pada Stasiun 2, 3 dan 4 memiliki Indek Dominansi yang hampir sama, maka hal ini menunjukkan bahwa di dalam komunitas tidak terdapat spesies yang secara ekstrim mendominansi spesies lainnya. Secara ekologis perairan kondisi ini menunjukkan bahwa kondisi perairan dalam keadaan stabil dan kondisi lingkungan cukup prima.

Analisis Pearson Correlation jenis Udang pada setiap stasiun pengamatan guna mengetahui adanya saling hubungan sebaran setiap jenis udang antar stasiun (tabel 8).

Tabel 8. Nilai Pearson Correlation (r) dan P-Value untuk Setiap Jenis Udang

\begin{tabular}{cllcll}
\hline No & \multicolumn{2}{c}{ Korelasi Antara } & $\begin{array}{c}\text { Correlation } \\
\text { Pearson }\end{array}$ & $\begin{array}{c}\text { P- } \\
\text { Value }\end{array}$ & Keterangan \\
\hline 1 & $\begin{array}{l}\text { Penaeus } \\
\text { monodon }\end{array}$ & $\begin{array}{l}\text { Penaeus } s p \\
(2)\end{array}$ & 0.968 & 0.032 & $\begin{array}{l}\text { Korelasi bersifat positif } \\
\text { dengan tingkat 96\% }\end{array}$ \\
2 & $\begin{array}{l}\text { Metapenaeus } \\
\text { affinis }\end{array}$ & $\begin{array}{l}\text { Penaeus } \\
\text { latisulcatus } \\
\text { Penaeus sp } \\
\text { Penaeus } \\
\text { indicus }\end{array}$ & -0.830 & 0.082 & $\begin{array}{l}\text { Korelasi bersifat negatif } \\
\text { dengan tingkat 83\% } \\
\text { Korelasi bersifat positif } \\
\text { dengan tingkat 83\% }\end{array}$ \\
\hline
\end{tabular}

Hasil analisis korelasi menunjukkan bahwa terdapat hubungan antara kemelimpahan beberapa jenis udang, yaitu antara Penaeus monodon dengan Penaeus (2), Metapenaeus affinis dengan Penaeus latisulcatus, dan Penaeus sp (1) dengan Penaeus indicus.

Berdasarkan hasil penelitian pada Tabel 8 dapat diketahui bahwa nilai signifikansi p-value sebesar 0,032 terdapat hubungan Penaeus monodon dengan 
Penaeus sp (2) yang menunjukkan bahwa korelasi bersifat positif dengan tingkat $96 \%$, artinya hubungan bersifat searah. Misalnya jika udang Penaeus monodon memiliki jumlah populasi yang meningkat di suatu komunitas, maka Penaeus sp (2) juga mengalami peningkatan jumlah populasi. Pendekatan ekologis secara komunitas perairan maka dapat dimungkinkan hubungan tersebut dapat terjadi, karena lingkungan fisik habitat dari kedua jenis udang berada pada ekosistem terbuka dan relatif terpadu antara mangrove, terumbu karang dan padang lamun dengan kondisi yang agak tertutup oleh selat selat antar pulau kecil. Menurut Bengen (2000) dalam Romimoharto (2009), ekosistem padang lamun secara khusus sangat penting dan fungsional mendukung tingginya pemberian nutrien yang dapat memicu pertumbuhan epifit yang selalu berimbang pada daun lamun. Akibatnya banyak tumbuhan dan organisme jasad renik lain yang bersifat planktonik, baik fitoplankton ataupun zooplankton yang hidup berada pada lapisan permukaan air bawah mendapatkan suplai cahaya dan oksigen yang cukup untuk perkembangnnya (Fairhurst dan Graham, 2003 dalam Dini et al, 2013).

Hubungan Metapenaeus affinis dengan Penaeus latisulcatus menunjukkan bahwa korelasi bersifat negatif dengan tingkat 83\%, artinya hubungan bersifat tidak searah. Misalnya jika udang Metapenaeus affinis memiliki jumlah populasi yang meningkat di suatu komunitas, maka Penaeus latisulcatus akan mengalami penurunan jumlah populasi, dan sebaliknya. Sedangkan hubungan Penaeus sp (1) dengan Penaeus indicus menunjukkan bahwa korelasi bersifat positif dengan tingkat 83\%, artinya hubungan bersifat searah. Misalnya jika udang Penaeus sp (1) memiliki jumlah populasi yang meningkat di suatu komunitas, maka Penaeus indicus juga mengalami peningkatan jumlah populasi.

Analisis cluster variabel dan observation difungsikan untuk menghasilkan kelompok yang memiliki homogenitas yang tinggi di dalamnya dan heterogenitas yang tinggi antar kelompok. Metode ini adalah model pengelompokkan multivariate (peubah banyak) yang tujuan utamanya mengelompokkan objek berdasarkan karakteristik yang dimiliki (Syihabbudin, 2012 dalam Angella, 2012). Hasil analisis sebagai berikut (Gambar 1 dan 2).

Pada Dendogram Gambar 1. terlihat bahwa berdasarkan tingkat similaritas keberadaan dan tingkat kemelimpahannya, terdapat 3 kelompok udang yaitu: 
Kelompok 1 : Penaeus latisulcatus, Penaeus indicus, dan Penaeus sp (1), Penaeus sp (2) dan Penaeus monodon

Kelompok 2 : Metapenaeus affinis

Kelompok 3 : Macrobrachium sp

Menurut Indrawan, $d k k$ (2007), suatu kondisi lingkungan dapat mempengaruhi pertumbuhan dan perkembangan makhluk hidup. Terjadinya pengelompokkan kemungkinan disebabkan oleh kedekatan lokasi geografis. Dimana suatu fenotip individu merupakan ekspresi dari genotip dan lingkungan serta lokasi geografis dan kualitas air yang relatif sama.

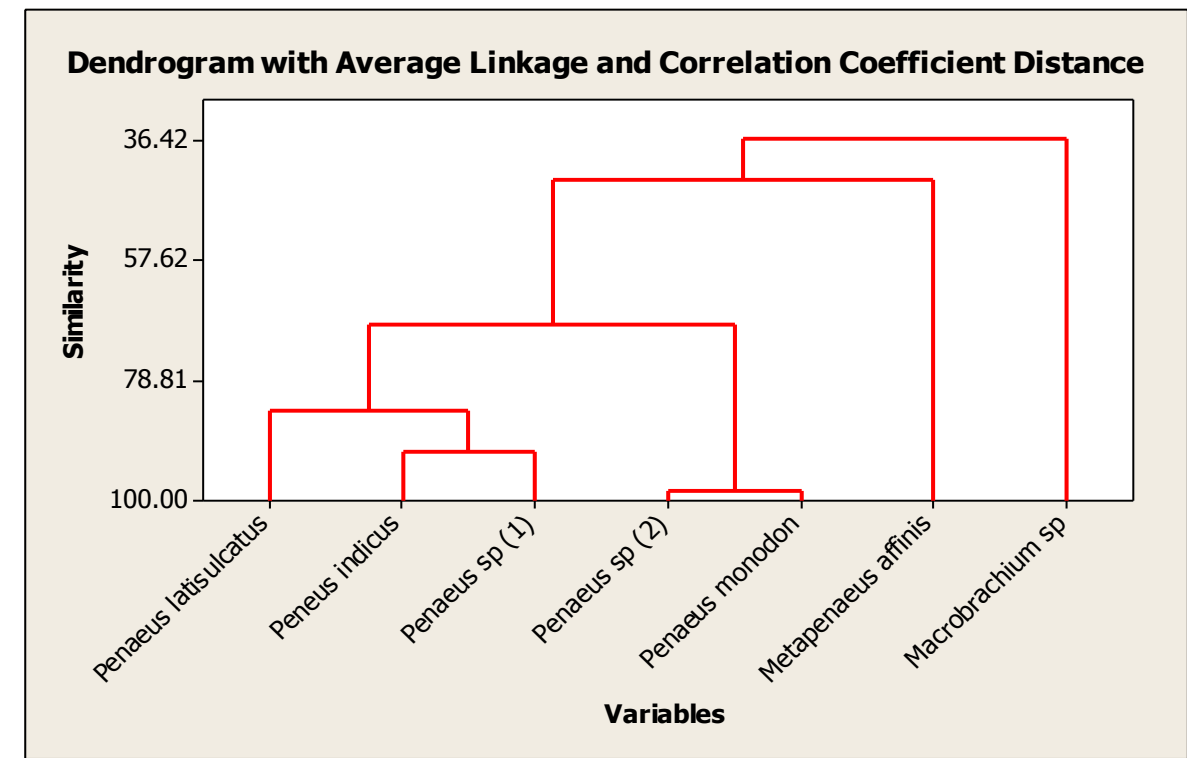

Gambar 1. Dendogram Hasil Analisis Cluster Variabel antar Jenis Udang

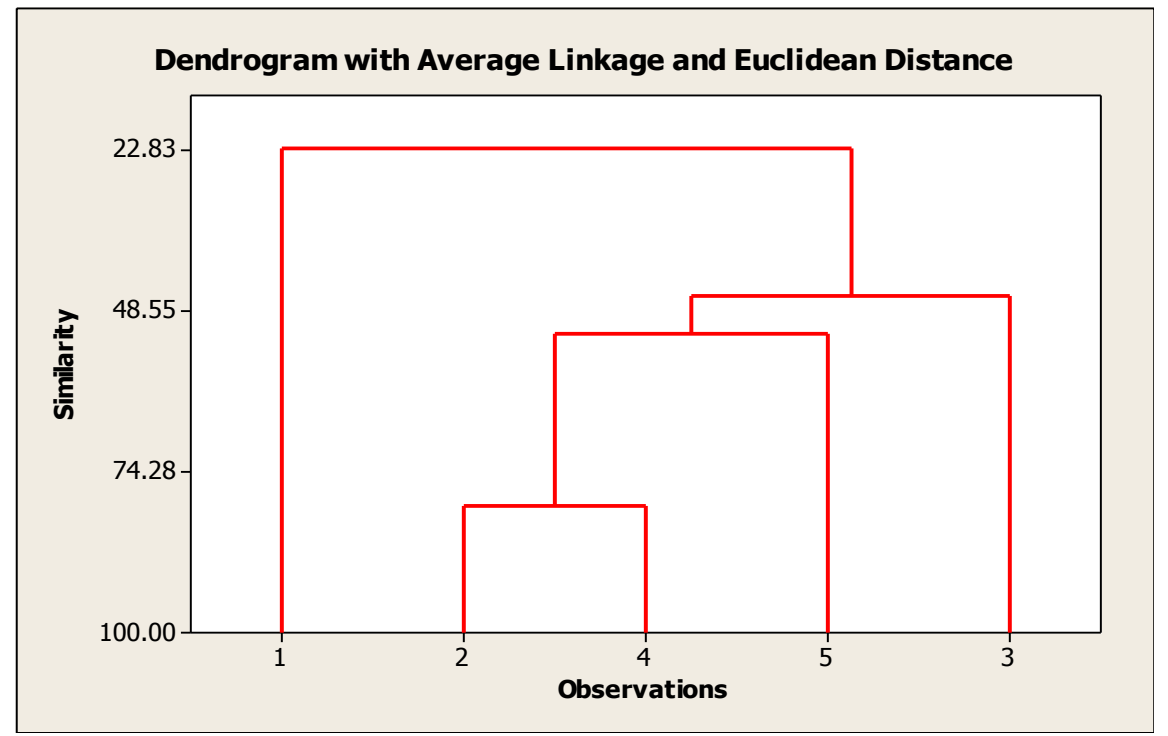

Gambar 2. Dendogram Hasil Analisis Cluster Observation antar Stasiun 
Pada Gambar 2. dapat dilihat bahwa berdasarkan tingkat similaritas keberadaan dan tingkat kemelimpahan udangnya terdapat 2 kelompok pengamatan yaitu: Kelompok 1:Stasiun 1; Kelompok 2: Stasiun 2, Stasiun 3, Stasiun 4 dan Stasiun 5. Keempat stasiun penelitian udang memiliki tingkat similaritas 46,26\%. Lokasi stasiun 2 dan stasiun 4 memiliki tingkat similaritas 79,86\%. Lokasi stasiun 2, stasiun 4 dan stasiun 5 memiliki tingkat similaritas $52,42 \%$.

Dari kedua kelompok diatas, dapat dapat diintepretasikan bahwa tingkat similaritas udang umumnya adalah rendah. Artinya spesies udang pada kelima stasiun penelitian udang tidak saling berhubungan. Hal ini terkait dengan Tabel 4.4 dimana tidak semua spesies udang terdapat pada seluruh stasiun.

Menurut Brower et al (1990) dalam Sembiring (2008), dua komunitas yang dibandingkan relatif sama apabila indeks kesamaan komunitas lebih besar atau sama dengan 50\%, sebaliknya jika indeks kesamaan komunitas lebih kecil dari 50\%, maka kedua komunitas yang dibandingkan itu dapat dianggap sebagai dua komunitas yang berbeda.

Dari hasil penelitian mendapatkan bahwa kesamaan komunitas antara Stasiun 2 dengan stasiun 3, 4 dan 5 yang secara fisik ekologis sama karena merupakan alur selat, sedimen pasir dengan ilalang laut yang cukup dominan dan memiliki tingkat similaritas sebesar 46,26\%. Secara umum jenis udang yang dijumpai sesuai dengan kondisi kebutuhan secara fisiologis khususnya toleransi terhadap konsentrasi salinitas. Sedangkan nilai similaritas paling tinggi adalah antara stasiun 2 dengan stasiun 4 mencapai nilai $79,86 \%$.

\section{KESIMPULAN}

Dari Jenis udang ditemukan 7 (tujuh) spesies udang yaitu: Penaeus latisulcatus, Metapenaeus affinis, Penaeus sp (1), Penaeus sp (2), Penaeus indicus, Penaeus monodon dan Macrobrachium sp. Hasil analisis korelasi menujukkan bahwa terdapat hubungan antara kemelimpahan beberapa udang, yaitu antara Penaeus monodon dengan Penaeus (2), Metapenaeus affinis dengan Penaeus latisulcatus, dan Penaeus sp (1) dengan Penaeus indicus. Tingkat similaritas udang antar tiap stasiun pengamatan adalah tinggi dan terdiri dari 2 (dua) kelompok, yaitu kelompok 1 : hanya mencakup Stasiun 1. Lokasi stasiun 1 dan keempat lokasi stasiun penelitian udang lainnya hanya 
memiliki tingkat similaritas 22,83\%. Kelompok 2 : Stasiun 2, Stasiun 3, Stasiun 4 dan Stasiun 5. Lokasi stasiun 2, stasiun 4 dan stasiun 5 memiliki tingkat similaritas 52,42\%. Lokasi stasiun 2 dan stasiun 4 memiliki tingkat similaritas 79,86\%. Sifat fisik kimia pada Selat Teluk Sepaku Kelurahan Pulau Buluh Kecamatan Bulang Kota Batam (suhu, salinitas, pH, DO, DHL, Nitrat, Fosfat dan Amonia) masih tergolong baik untuk kehidupan biota laut, termasuk udang.

\section{REFERENCE}

Dantes, N. 2012. Metode Penelitian. Andi Yogyakarta, Yogyakarta.

Dini, L., Kasim, M., dan Palupi, R D. 2013. Kelimpahan dan Komposisi Ukuran Panjang Udang Ronggeng (Lysiosquilla maculata) pada Habitat Yang Berbeda di Perairan Kauduma Desa Petetea'a Kabupaten Buton Utara. Jurnal Mina Laut Indonesia. Fakultas Perikanan dan Ilmu Kelautan Universitas Haluoleo, Kendari.

Idrawan, M., Primack R.B dan J. Supriatna. 2007. Biologi Konservasi. Penerbit PT. Yayasan Obor Indonesia, Jakarta.

Juliani. 2009. Udang Jerbung. http://www.vivacious86.com. [Diunduh Tanggal 10 Februari 2012 Jam 13:42].

Lovett, D. L. A. Guide to The Shrimps, Prawns, Lobsters, and Crabs of Malaysia and Singapore. Universiti Pertanian Malaysia, Malaysia.

Min, T.S., Yong, L.P., Senta, T., Kuang, H.K., Heong, R.L.S., Whay, L.N., Foen, S.L.S., Nam, N.B., Seng, G.C., Heng, A.L.C., dan Hock, W.P. 1996. A Colour Guide To The Fishes Of The South China Sea And The Andaman Sea. Departemen Penelitian Perikanan Laut Singapore. Singapure.

Nontji, A. 1993. Laut Nusantara. Penerbit Djambatan, Jakarta.

Nybakken, J. W. 1992. Biologi Laut. Suatu Pendekatan Ekologis. Alih Bahasa Oleh H. M. Eidman. PT. Gramedia. Jakarta.

Odum, E. P. 1998. Dasar-dasar ekologi Edisi Ketiga. Penerbit Gadjah Mada University Press. Yogyakarta.

Romimohtarto, K. dan Juwana, S. 2009. Biologi Laut: Ilmu Pengetahuan tentang Biota Laut. Penerbit Djambatan, Jakarta.

Saputra, S.W. 2007. Buku Ajar: Mata Kuliah Dinamika Populasi. Universitas Diponegoro, Semarang.

Sugiarto, T. 2010. Budidaya Udang. Bandung: PT. Sinergi Pustaka Indonesia.

Suwignyo, S., B. Widigdo, Y. Wardiatno dan M. Krisanti. 2005. Avertebrata Air Jilid 2. Jakarta: Penerbit Penebar Swadaya.

Sembiring, Herlina. 2008. Tesis : Keanekaragaman dan Distribusi Udang serta Kaitannya dengan Faktor Fisik Kimia di Perairan Pantai Labu Kabupaten Deli 
Serdang Sumatera Utara. Medan: Universitas Sumatera Utara.

Treece, GD and M.E. Yates. 1990. Laboratory Manual For The Cultural Of Penaeidae Shrimp Larvae. Texas: Penerbit Tamu-SG-88-202 (R).

Wibisono, T. 2005. Pengantar Ilmu Kelautan. Jakarta: Penerbit PT. Grasindo.

Yudistira, Vicky. 2009. Jenis-Jenis Udang Potensial. http://www.bisnisukm.com. [Diunduh Tanggal 12 Februari 2012. Jam 13:59].

Zaldi. 2009. Buku Ajar: Mata Kuliah Avertebrata Air "Filum Crustacea". Fakultas Perikanan dan Ilmu Kelautan Universitas Muhammadiyah. Pontianak. 